\title{
Identification of tetrodotoxin-producing Shewanella spp. from feces of food poisoning patients and food samples
}

\author{
Duochun Wang ${ }^{1 \dagger}$, Yonglu Wang ${ }^{2 \dagger}$, Hongnan Huang ${ }^{3}$, Jie Lin ${ }^{3}$, Di Xiao ${ }^{1}$ and Biao Kan ${ }^{1 *}$
}

\begin{abstract}
Shewanella spp. is infrequently recovered from clinical specimens. Following two outbreaks of food poisoning, eight Shewanella spp. strains were obtained from the fecal specimens of patients, food and food processing-related materials. Tetrodotoxin (TTX) was identified in the culture supernatants of these strains, and the toxin's biological activity was detected using a mouse bioassay. This study suggested that Shewanella strains can colonize and survive in human intestines. The study also raises the issues of the accumulation of TTX produced by Shewanella in food and the possible role of TXX-producing Shewanella in food poisoning.
\end{abstract}

Keywords: Tetrodotoxin, Shewanella, Food poisoning

\section{Background}

Shewanella spp. is Gram-negative, motile bacilli that belong to the order Alteromonadales and the family Alteromonadceae, within the gamma subdivision of the Proteobacteria. Human infections with members of the genus Shewanella are rare and mainly involve the ears [1] and soft tissue [2-5]. The isolation of Shewanella spp. from patients with diarrhea, poultry and livestock has also been reported [6]. In most instances, the isolation of has occurred in the absence of clinical disease and has been considered to involve only colonization, rather than an active infection [7]. However, in recent years, it was found that Shewanella spp. can produce tetrodotoxin (TTX) [8]. TTX and its analogs (TTXs) have been detected in a wide variety of marine animals [9]. It has been suggested that TTX is a secondary metabolite produced by symbiotic bacteria in marine organisms that gradually accumulates in the bodies of marine organisms through the food chain $[8,10]$. With the

\footnotetext{
* Correspondence: kanbiao@icdc.cn

${ }^{\dagger}$ Equal contributors

'State Key Laboratory for Infectious Disease Prevention and Control/ Collaborative Innovation Center for Diagnosis and Treatment of Infectious Diseases, National Institute for Communicable Disease Control and Prevention, Chinese Center for Disease Control and Prevention, P.O. Box 5, Changping, Beijing, China

Full list of author information is available at the end of the article
}

source of TTX still a controversial issue, the exact origin of TTX in the food chain is unknown.

\section{Study design and results}

On Sept. 29th and Oct. 2nd, 2007, two food poisoning incidents occurred following banquet dinners at two different restaurants in Ma'anshan City, China. A total of 50 people attended one dinner, and 152 people attended the other dinner. Of these individuals, 16 and 22 people, respectively, showed symptoms of food poisoning in $1-4 \mathrm{~h}$, with abdominal pain $(n=35)$, diarrhea $(n=35$, usually more than five times and consisting of yellow, watery stool), vomiting $(n=24)$, nausea $(n=16)$, poor peripheral circulation with dizziness $(\mathrm{n}=20)$ and/or headache $(n=14)$ lasting for several hours. Specimens were collected in these two poisoning investigations and inoculated in selective media (WS, SS, EMB or TCBS Agar) after bacterial enrichment (see Additional file 1: Materials and methods). No common intestinal pathogens were isolated, such as Vibrio cholerae, Salmonella, Shigella and enteropathogenic Escherichia coli, but eight strains of Shewanella spp. were isolated from the specimens, which included hand swabs of a

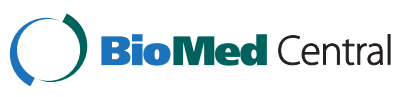

(c) 2013 Wang et al.; licensee BioMed Central Ltd. This is an Open Access article distributed under the terms of the Creative Commons Attribution License (http://creativecommons.org/licenses/by/2.0), which permits unrestricted use, distribution, and reproduction in any medium, provided the original work is properly cited. 
restaurant chef (strains MAS2723 and MAS2762), swabs of a restaurant knife (MAS2729), anal swabs of four patients (MAS2736, MAS2737, MAS2740 and MAS2741) and marinated beef (MAS2758). These strains were identified with biochemical tests and $16 S$ rDNA sequencing (Figure 1: seven strains were S. algae, except strain MAS2723, which might be a new species of Shewanella).

Because these patients were food poisoned and because TTX production has been reported for Shewanella strains [8], we measured TTX production by these isolates. TTX was detected from the sevenday culture supernatants by mass spectrometry assays (Figure 2). TTX extracts from cells and supernatants of the Shewanella spp. isolates were further subjected to an activity bioassay in mice (Table 1). After injection, TTX extracts from bacterial overnight cell cultures and supernatants and from sevenday cell cultures of all isolates did not induce symptoms of poisoning in the mice. In contrast, injection with TTX extracts from supernatants of seven-day cultures of all isolates caused the mice to show the same symptoms as those induced by a TTX standard in 0.5-13 minutes, including gait disorders, hindlimb weakness, convulsion and death. The mice in the control group had no obvious symptoms following the injection of $0.1 \%$ acetic acid.

\section{Conclusion}

The Shewanella strains recovered from the fecal samples of the food poisoning patients may present evidence of the survival of TTX-producing Shewanella in human intestines. To date, there is still no direct evidence to show that TTX produced by Shewanella spp. is related to food poisoning. Considering a previous report of Shewanella isolation from food poisoning patients [6] and our investigation, in which strains were also obtained from food, hand swabs of a restaurant chef and a knife, these findings suggest contamination with Shewanella through the fecaloral route and indicate the need for detection and studies of Shewanella in food poisoning, especially if caused by TTX. The limitations of this study are that no blood samples were obtained for the detection of anti-TTX antibody, and no food sample was screened for TTX. Studies indicate that TTX accumulation in the puffer fish occurs through the food chain, consisting of several steps and starting with marine bacteria as the primary source [8]. In this study, very weak, slow TTX production by the Shewanella strains under common culture conditions was also observed. We suspected that weak accumulation of TTX in seafood might have caused the poisoning symptoms of the patients, as the recovered Shewanella strains were in fact the bacteria colonizing the seafood.

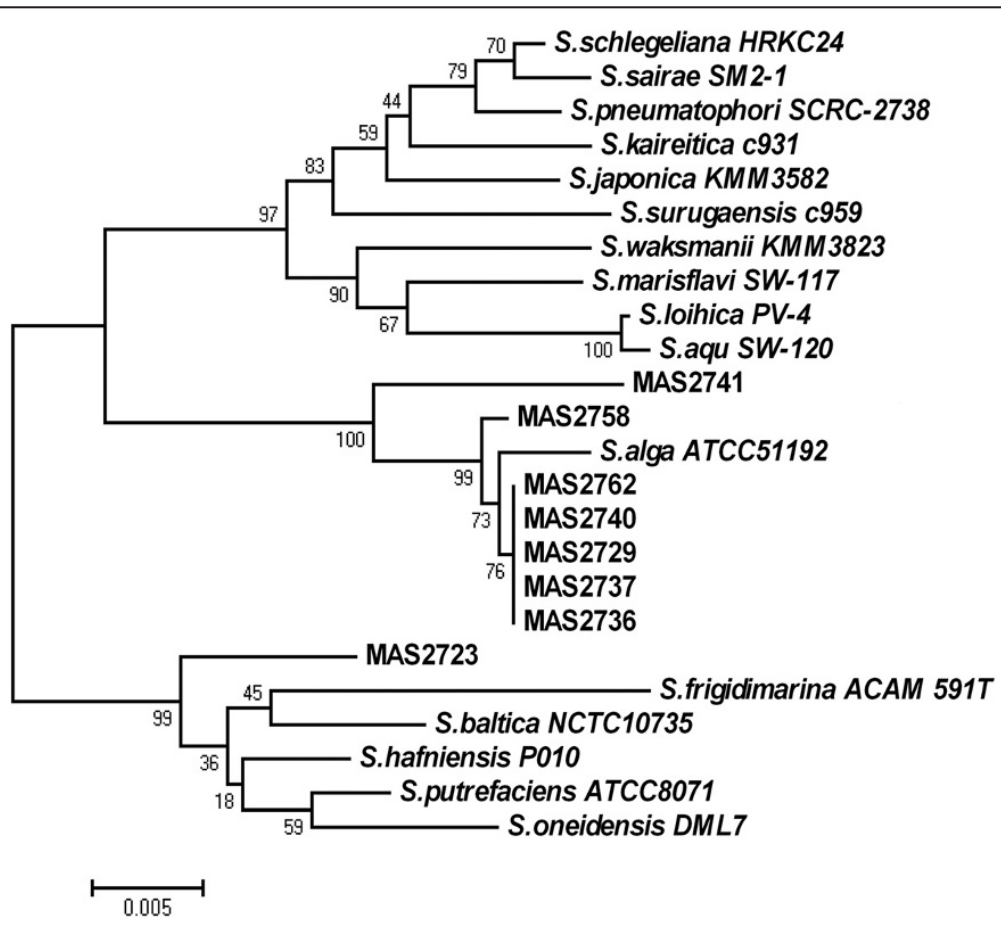

Figure 1 16S rDNA gene phylogenetic tree of Shewanella spp. strains from this study and GenBank. The GenBank accession numbers of the 165 rDNA of eight Shewanella spp. strains, MAS2723, MAS2729, MAS2736, MAS2737, MAS2740, MAS2741, MAS2758 and MAS2762, are GQ372872-79. Bar, 0.005 substitutions per nucleotide position. 


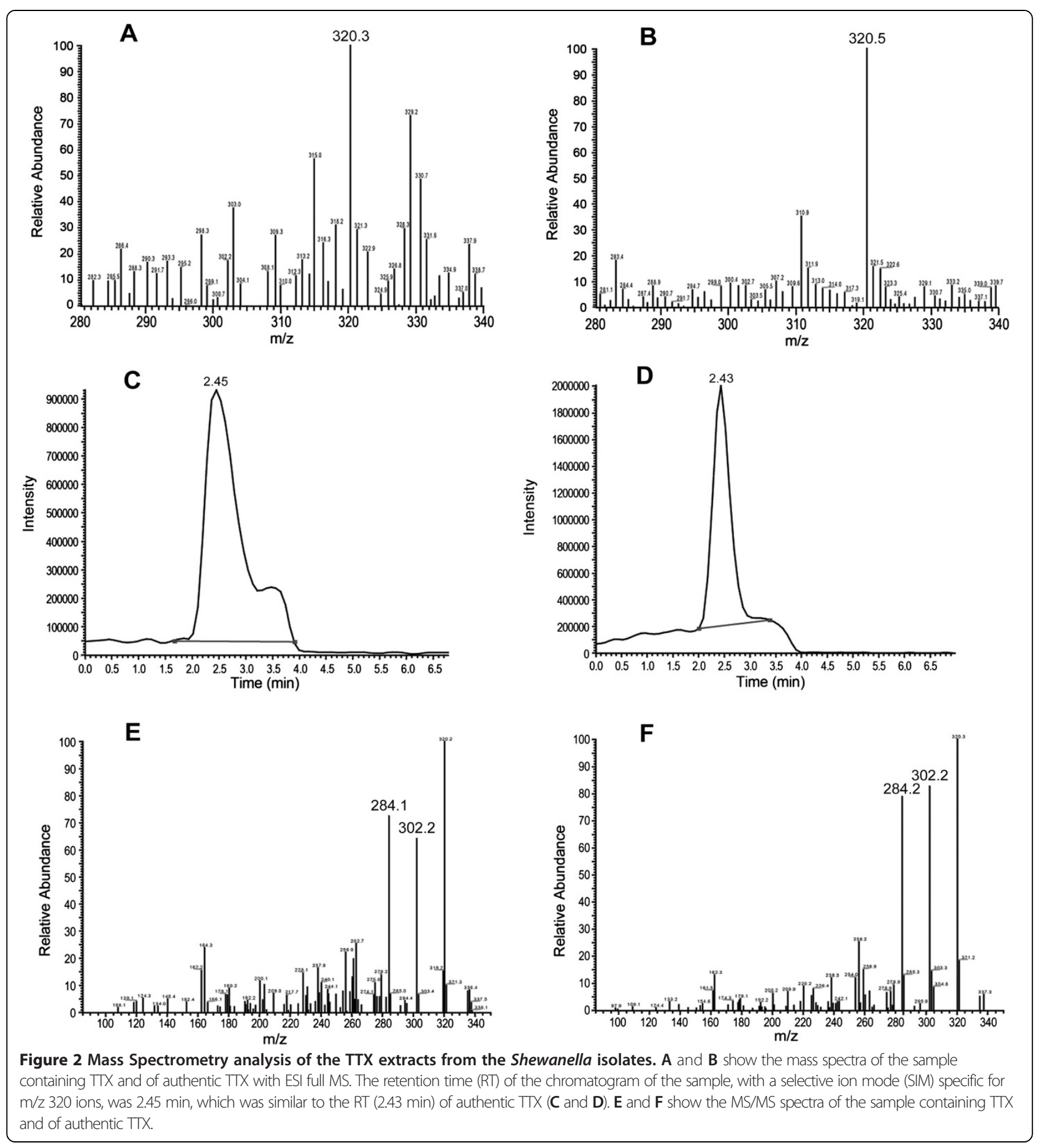


Table 1 Mouse bioassay of the toxicity of TTX extracts from the Shewanella spp. isolates

\begin{tabular}{|c|c|c|c|c|}
\hline Item & Individual & $\begin{array}{c}\text { Average } \\
\text { weight (g) }\end{array}$ & $\begin{array}{l}\text { Mortality } \\
(\%)\end{array}$ & $\begin{array}{c}\text { Mean lethal } \\
\text { time (min) }\end{array}$ \\
\hline TTX extracts from cells & 24 & 20.7 & 0 & - \\
\hline \multicolumn{5}{|l|}{ (overnight culture, 8 isolates) } \\
\hline TTX extracts from supernatants & 24 & 20.3 & 0 & - \\
\hline \multicolumn{5}{|l|}{ (overnight culture, 8 isolates) } \\
\hline TTX extracts from cells (7-day & 24 & 19.8 & 0 & - \\
\hline \multicolumn{5}{|l|}{ culture, 8 strains) } \\
\hline TTX extracts from supernatants & 24 & 20.6 & 100 & 2.5 \\
\hline \multicolumn{5}{|l|}{ (7-day culture, 8 isolates) } \\
\hline TTX standard, $2.2 \boldsymbol{\mu} \mathrm{g} / \mathrm{ml}$ & 3 & 20.4 & 100 & 3 \\
\hline $0.1 \%$ acetic acid & 3 & 19.7 & 0 & - \\
\hline
\end{tabular}

\section{Additional file}

Additional file 1: Materials and methods.

\section{Competing interests}

The authors declare that they have no competing interests.

\section{Authors' contributions}

Conceived and designed the experiments: BK DW. Performed the experiments: DW YW HH JL DX. Analyzed the data: DW YW HH JL. Contributed reagents: HH JL. Discussion and wrote the paper: DW YW BK. All authors read and approved the final manuscript.

\section{Acknowledgements}

This work was supported by grants from the National High Technology R\&D Program of China (863 Program) (2006AA02Z425), the NSFC of China (30872260), and the National Priority Program for Prevention and Control of Infectious Diseases (2008ZX10004-012).

\section{Author details}

${ }^{1}$ State Key Laboratory for Infectious Disease Prevention and Control/ Collaborative Innovation Center for Diagnosis and Treatment of Infectious Diseases, National Institute for Communicable Disease Control and Prevention, Chinese Center for Disease Control and Prevention, P.O. Box 5 Changping, Beijing, China. ${ }^{2}$ Ma'anshan Center for Disease Control and Prevention, Ma'anshan, China. ${ }^{3}$ Center for Diseases Control and Prevention of Fujian Province, Fujian, China.

Received: 9 April 2013 Accepted: 15 June 2013

Published: 20 June 2013

\section{References}

1. Holt HM, Sogaard P, Gahrn-Hansen B: Ear infections with Shewanella alga: a bacteriologic, clinical and epidemiologic study of 67 cases. Clin Microbiol Infect 1997, 3:329-334.

2. Chen YS, Liu YC, Yen MY, Wang JH, Wang JH, Wann SR, Cheng DL: Skin and soft-tissue manifestations of Shewanella putrefaciens infection. Clin Infect Dis 1997, 25:225-229.

3. Pagani L, Lang A, Vedovelli C, Moling O, Rimenti G, Pristera R, Mian P: Soft tissue infection and bacteremia caused by Shewanella putrefaciens. J Clin Microbiol 2003, 41:2240-2241.

4. Ternavasio-de-la-Vega HG, Angel-Moreno A, Hernandez-Cabrera M, PisosAlamo E, Bolanos-Rivero M, Carranza-Rodriguez C, Calderin-Ortega A, PerezArellano JL: Skin and soft tissue infections (patera foot) in immigrants. Spain. Emerg Infect Dis 2009, 15:598-600.

5. Goyal R, Kaur N, Thakur R: Human soft tissue infection by the emerging pathogen Shewanella algae. J Infect Dev Ctries 2011, 5:310-312.
6. Yang JC, Guo H, Xu JJ, Zhang L, Wang X, Jing HQ: Studies on the biological characters of the Shewanella isolates. Chinese J Zoonoses 2009 25:699-700.

7. Brink AJ, van-Straten A, van-Rensburg AJ: Shewanella (Pseudomonas) putrefaciens bacteremia. Clin Infect Dis 1995, 20:1327-1332.

8. Noguchi T, Arakawa O: Tetrodotoxin-distribution and accumulation in aquatic organisms, and cases of human intoxication. Mar Drugs 2008, 6:220-242.

9. Ritson-Williams R, Yotsu-Yamashita M, Paul VJ: Ecological functions of tetrodotoxin in a deadly polyclad flatworm. Proc Natl Acad Sci USA 2006, 103:3176-3179.

10. Narahashi T: Tetrodotoxin: a brief history. Proc Natl Acad Sci USA 2008, 84:147-154.

doi:10.1186/1757-4749-5-15

Cite this article as: Wang et al:: Identification of tetrodotoxin-producing Shewanella spp. from feces of food poisoning patients and food samples. Gut Pathogens 2013 5:15.

\section{Submit your next manuscript to BioMed Central and take full advantage of:}

- Convenient online submission

- Thorough peer review

- No space constraints or color figure charges

- Immediate publication on acceptance

- Inclusion in PubMed, CAS, Scopus and Google Scholar

- Research which is freely available for redistribution
C Biomed Central 